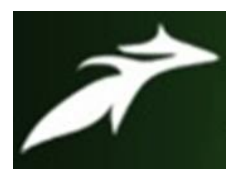

Ashish Kumar Pradhan et al, Int. Journal of Advances in Agricultural Science \& Technology,

Vol.8 Issue.10, October-2021, pg. 122-127

ISSN: 2348-1358

Impact Factor: 6.057

NAAS Rating: 3.77

\title{
TO FIND OUT THE CONSTRAINTS FOUND BY RESPONDENTS IN GETTING PMFBY AND SEEK THEIR SUGGESTIONS TO OVERCOME THE CONSTRAINTS IN DEOGARH DISTRICT OF ODISHA
}

\author{
Ashish Kumar Pradhan* \\ M.Sc. Ag. (Agricultural Extension and Communication) \\ Prof. (Dr.) Ms. Jahanara** \\ Professor \& Head, Department of Agricultural Extension and Communication, SHUATS \\ Dr. Dipak Kumar Bose**** \\ Associate Professor, Department of Agricultural Extension and Communication, SHUATS \\ DOI: 10.47856/ijaast.2021.v08i10.014
}

\begin{abstract}
Research study entitled "A Study on attitude of farmers towards Pradhan Mantri Fasal Bima Yojana in Deogarh District of Odisha" was under taken to elucidate the constraints faced by the farmers regarding Pradhan Mantri Fasal Bima Yojana and seek their suggestions. The constraints faced by the beneficiaries in PMFBY were Lack of knowledge regarding to PMFBY, lack of awareness of benefits of PMFBY, less compensatation offered in crop insurance scheme, delay in payment of compensatation. Rate of premium is not universal for all crops, on-line registration and assessment of risk complexity in PMFBY, unavailability of experts for assessment of loss at visit time, lack of coordination between banks and farmers and high rate of premium. Suggestion made by the beneficiaries to overcome the constraints in PMFBY were procedure of the scheme should be simplified, organization of awareness programmes for farmers regarding PMFBY, organization of training programmes on e-filling of insurance and benefit of the farmers, payment of premium by the government for farmers below the poverty regarding PMFBY, premium rate may be decreased, avoid delay in payment of compensatation, increase the number of extension agents, improve linkage between banks and farmers, unit area may be of individual or a village level improve socio-economic conditions of the farmers and increase the insurance agents in rural areas.
\end{abstract}

Keywords: PMFBY, constraints, knowledge, etc. 


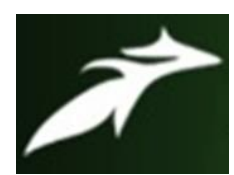

Ashish Kumar Pradhan et al, Int. Journal of Advances in Agricultural Science \& Technology, Vol.8 Issue.10, October-2021, pg. 122-127

ISSN: 2348-1358

Impact Factor: 6.057

NAAS Rating: 3.77

\section{Introduction}

Agriculture is the backbone of Indian economy. The history of agriculture in India dates back to Indus valley civilization and even before that India ranks first in the world with highest net cropped area followed by United States and China. Agriculture contributes to only around 17.00 per cent of India's Gross Domestic Product (GDP) but it provides employment to around 60.00 per cent of our population. The economic contribution of agriculture to India's GDP is steadily declining with the country's broad-based economic growth(wikipedia.org).

Indian agriculture is said to be gamble of monsoon. Traditional practices, non transfer of tacit knowledge and weak understanding of market is often associated with lower returns in agriculture. Agriculture production and farm incomes in India are frequently affected by natural disasters such as droughts, floods, cyclones, storms, landslides and earthquakes etc. The weather is the greatest adversary, something that can never be controlled by man. The majority of Indian population is largely dependent on agriculture; therefore, a bad season does not affect an enterprise rather, it breaks the spine of larger segment of population. The growth of this sector is an essential prerequisite for inclusive growth as well as reduction of poverty in India. But Indian Agriculture suffers from serious problems in side of populations and one of them is excessive risk and uncertainty faced by farmers. (Ghanghas 2018).

Indian agricultural environment has undergone numerous structural changes due to change in governmental policies. Yet, farming has come a long way since, then nevertheless, farmers are still at mercy of the heavens. It being the function of physical, socio-institutional, technoeconomic factors which are dynamic in nature keeps on changing with the basis objective of increasing production and generation of food grain surplus. To provide some relief to farmers from disasters, states have evolved few instruments such as, Input subsidy, Minimum Support Price (MSP) and crop insurance. etc. Input subsidy provides minimum support to farmers to continue with farming in subsequent post damage season and thus becomes operational only when there is a significant damage due to drought or excessive rainfall On the other hand, MSP is beneficial to farmers in the event of glut of that product in the market. Thus, there utility is significant in selected instances only. It is quite common to observe significant 


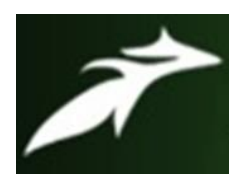

Ashish Kumar Pradhan et al, Int. Journal of Advances in Agricultural Science \& Technology, Vol.8 Issue.10, October-2021, pg. 122-127

ISSN: 2348-1358

Impact Factor: 6.057

NAAS Rating: 3.77

decline in farm produce due to climatic factors and there is no assistance available to farmers to overcome this dip in production. Still, agriculture is demographically the broadest economic sector and plays a significant role in the overall socio-economic fabric of India.

The risk bearing capacity of marginal and small farmers in the country is very limited. Agricultural insurance is considered as one of the important mechanism to effectively address the risks to farm production and income resulting from various natural and manmade events. Different forms of experiments on agricultural insurance were started from 1985 onwards.

The first nation-wide crop insurance scheme was the Comprehensive Crop Insurance Scheme (CCIS) (Kharif, 1985)- This scheme was based on an area approach and area units were identified for the purpose of assessing indemnity. This was replaced by National Agriculture Insurance Scheme (NAIS) in Rabi 1999-2000, which was further changed to the Modified National Agricultural Insurance Scheme (MNAIS) during Rabi 2010-11. Apart from these schemes, several other pilot projects such as Seed Crop Insurance (1999), Farm Income Insurance Scheme (Rabi 2003-04) and Weather Based Crop Insurance Scheme (Kharif 2007) were implemented from time to time (Maruthi 2018).

\section{Pradhan Mantri Fasal Bima Yojana (PMFBY)}

Realizing the limitations of existing system of crop insurance that was not able to meet the needs of farmers, government announced a new crop insurance program. PMFBY scheme became operational from 13 February 2016, with an objective to provide adequate insurance coverage and financial support to the farmers in the event of crop failure (Ghanghas 2018).

\section{Goals of the PMFBY}

1. To provide insurance coverage and financial support to the farmers in the event of any of the notified crops as a result of natural calamities, pests and diseases.

2. To stabilize the income of farmers to ensure their continuance in farming. 


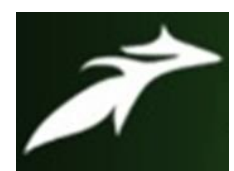

Ashish Kumar Pradhan et al, Int. Journal of Advances in Agricultural Science \& Technology, Vol.8 Issue.10, October-2021, pg. 122-127

3. To encourage farmers to adopt innovative and modern agricultural practices.

4. To ensure flow of credit to the agriculture sector.

\section{Research Methodology}

Descriptive research design was followed for the present study. Barkote block of Deogarh district of Odisha was selected by purposive sampling for the present study. Total number of villages were selected by random sampling. Total 120 number of respondents were selected for the present study. The data was collected by using the pre structured interview schedule. Data analysis is done through frequency, percentage and Rank distribution using statistical tools.

For calculating percentage, frequency was multiplied by 100 and divided by total number of respondents.

$\mathrm{P}=\mathrm{X} / \mathrm{N} \times 100$

Where, $\mathrm{P}=$ Percentage

$\mathrm{X}=$ Frequency of the respondents

$\mathrm{N}=$ Total number of respondents

\section{Results and Discussion}

Table : Distribution of respondents according to their Constraints faced by respondents in PMFBY.

\begin{tabular}{|c|c|c|c|c|}
\hline $\begin{array}{l}\text { S } \\
\text { No. }\end{array}$ & Constraints & $\begin{array}{c}\text { Frequency } \\
(\mathbf{N}=\mathbf{1 2 0})\end{array}$ & percentage & Rank \\
\hline 1 & Low awareness about PMFBY. & 87 & 72.5 & II \\
\hline 2 & $\begin{array}{l}\text { Problem of improper reporting in case of } \\
\text { crop loss. }\end{array}$ & 73 & 60.84 & IV \\
\hline 3 & $\begin{array}{l}\text { Unavailability of source for doubt } \\
\text { clarification. }\end{array}$ & 66 & 55.00 & $\mathrm{~V}$ \\
\hline 4 & Delay payment of insurance claims. & 104 & 86.67 & I \\
\hline 5 & $\begin{array}{l}\text { Negative attitude of farmers towards this } \\
\text { scheme. }\end{array}$ & 27 & 22.5 & IX \\
\hline
\end{tabular}




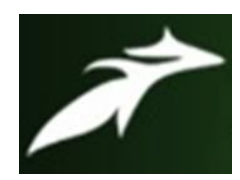

Ashish Kumar Pradhan et al, Int. Journal of Advances in Agricultural Science \& Technology, Vol.8 Issue.10, October-2021, pg. 122-127

ISSN: 2348-1358

Impact Factor: 6.057

NAAS Rating: 3.77

\begin{tabular}{|l|l|l|l|l|}
\hline 6 & Expert unavailable for assessment of crop & 52 & 43.33 & VII \\
\hline 7 & $\begin{array}{l}\text { Lack of well-trained insurance } \\
\text { professionals }\end{array}$ & 83 & 69.17 & III \\
\hline 8 & Insufficient bank facilities in rural area & 61 & 50.83 & VI \\
\hline 9 & Lack of education of farmers. & 37 & 30.83 & VIII \\
\hline
\end{tabular}

According to the above table Delay payment of insurance claims ranks at number I for constraints faced by the respondents, Low awareness about PMFBY (rank II), Lack of welltrained insurance professionals (rank III), Problem of improper reporting in case of crop loss. (rank IV), Unavailability of source for doubt clarification (rank V), Insufficient bank facilities in rural area ranks at number VI, Expert unavailable for assessment of crop (rank VII), Lack of education of farmers (rank VIII) and Negative attitude of farmers towards this scheme (rank IX).

This shows that most of the farmers had identified delay payment of insurance claim as the major constraint. Low awareness about PMFBY comes after it and lack of well-trained insurance professional follows after it. Overall, Government and extension agencies should notice the constraints and adopt the measures to make PMFBY a more popular and acceptable scheme among the farmers of India.

\section{Suggestions offered by respondents:}

Establishment of more number of banks in rural areas.

$>$ The government should pay the premium for farmers below the poverty line.

Due attention should be given for paying the claim amount in proper time.

Sum amount should be raised.

Efforts should be directed to use of information technology in dissemination of the knowledge on PMFBY to the farming community. 


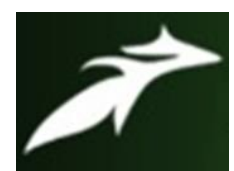

Ashish Kumar Pradhan et al, Int. Journal of Advances in Agricultural Science \& Technology, Vol.8 Issue.10, October-2021, pg. 122-127

ISSN: 2348-1358

Impact Factor: 6.057

NAAS Rating: 3.77

\section{Conclusion}

Agriculture is the backbone of Indian economy. To meet the needs of farmers, government announced a new crop insurance program PMFBY scheme. Respondents faced various constraints while adopting the PMFBY scheme. Delay payment of insurance claims, low awareness about PMFBY, lack of well-trained insurance professionals were some of the major constraints they were facing. To tackle the problems faced by respondents, attentive and loyal work of government agencies and insurance companies are necessary. Awareness drives should be organized to increase the awareness of farmers regarding PMFBY scheme. Some suggestions given by the respondents are establishment of more number of banks in rural areas, the government should pay the premium for farmers below the poverty line, due attention should be given for paying the claim amount in proper time, sum amount should be raised and so on.

\section{References}

[1]. Ashalata, G. S. and Prabhu, M. 2017. Pradhan Mantri Fasal Bima Yojana (PMFBY) an awareness in Chamarajanagara district. International Journal of Economics and Business Review. 5 (12).

[2]. Ghanghas, B. S. 2018. Awareness of Pradhan Mantri Fasal Bima Yojana among farmers of Haryana State. Journal of Pharmacognosy and Phytochemistry. 7 (4): 1912-1914.

[3]. Gupta, S. C. 2018. A critical appraisal of Pradhan Mantri Fasal Bima Yojana (PMFBY). With special reference to Rabi fasal 2016-2017 in Rajasthan state. Remarking an analyzation. 3 (9).

[4]. Maruthi, 1. 2018. Uptake analysis of Pradhan Mantri Fasal Bima Yojana Karnataka. A project report of Institute for Social and Economic Change, Bangalore.

[5]. Padmaja, P., Mahendiran, S., Rao, M. B. V., Prasad, S. R., Bhavani, S. and Jyotsana, J. 2017. Understanding the potential of Crop insurance in India: A study of Pradhan Mantri Fasal Bima Yojana (Prime Minister's Crop Insurance Scheme). Research Studies. Centre for Budget and Policy Studies. 